追 加

$$
\text { 鳥取大学 桑原 }
$$

覀性 腫昜に 骨盤切除を 最適当と思うほどでなかつ た.ただその際, 主静脉を含めて諸静脉を先ず結禁し， 後動脉結紮を行うことを自ら注意した。
追 加

神戸医大整形 柏木大治

大眼骨上端から発生した肉腫に対して hind-quarter-amputation をなした。

術後 2 年後に肉腫は局所に再発 Anurie となつて死

亡した症例の経験を追加する.

\title{
広沉なる転移を起こした骨細網肉腫と思われる一例
}

\author{
長崎大学医学部整形外科（主任: 永井三郎教授） \\ 朝 長一 一 原和夫 \\ 村田敬 典 岡本 雄 三
}

\section{A Case of Primary Reticulum Cell Sarcom of Bone with Wide Spread Involvement in Skeletal System.}

By

\author{
H. Tomonaga, K. Mihara, Y. Murata \\ and Y. Okamoto \\ Department of Orthopedic Surgery, School of Medicine, \\ Nagasaki University (Director: Prof. S. Nagai)
}

Oberlingは骨の Reticuloendothelial より原発する 畽瘍に対して骨原発性細網肉腫と名ずけ Parker and Jackson が臨床的及び組織学的見地からこの細網肉腫 の本態について論じ, Edwards, Sherman and Snyder はこの畽昜のレ線所見からこれら 細網肉腫を考察し た. その後 Coley, Mc. Comack, Ivins and Dahlin, Hausberg and Kenin, Schobinger 等がこの細網肉 腫の臨床的, レ線的, 組織学的な所見から診断を下し た多数の症例, 報告がある. 最近吾々も骨の細網肉腫 と思える 1 例を経験し， しかも殆んどの全身骨に転位 を起こしたもので他の骨腫瘍と鑑別上非常に困難であ つたが，臨床的経過，レ線所見及び組織学的検索の結 果一応細網肉腫と断定さるべきものであると考えられ るので報告する次第である.

\section{症例： 合 27 才商業.}

既往歴, 家族歴：に特記すべきものはない.

現病歴：昭和 33 年 8 月 10 日頃から何等誘因と思 えるものなく背部痛を訴えるようになり，某医に受診 肋間神経痛と診断され対症療法を受けていたが疼痛は 消退することなく次第に増加したため 10 月に入つて 他の医師に医療を乞い胸部レ線撮影を受け肋骨カリエ
スと診断され入院の上，P.A.S. 及び S.M. の使用を受 けた。

1 ケ月後やや症状は軽快したので退院し，その後自 宅で様子をみるよう指示され休養をとつていたが，軽 度の疼痛を背部から腰部にかけて感じていたと云う。 34 年 1 月 10 日階段よりころげ落ちて腰部を強打し, その後より強烈な腰痛を招来し, 坐位, 立位, 歩行に 際しても又仰臥位に対しても痛みを感じ，側卧位で安 静を保つていたと云5．2月 10 日頃から咳嗽，喀痰 が出るようになり，咳嗽に際して腰部から左脚に放散 する痛みを感じるようになつた。2月 25 日頃から熱 発し, 腰痛も増強せる為 2 月 28 日吾々の外来を訪門 した. 初診時一般状態悪く起立, 坐居不能で, 右側臥 位をとり両下肢は屈曲位でやや拘縮をきたし，背部， 腰部に圧痛があり，左膝関節にも疼痛を訴えた。しか し局所に熱感も腫脹も触知しなかつた. 直ちに入院し 胸部, 腰部, 左膝関節のレ線撮影を行つたところ右第 6 胁骨, 左第 8 助骨に溯漫性に腫脹せる骨硬化像を認 め, 左鎤骨に円形の透明肩，又第 III腰椎に著明な骨破 壊像, 左大眼骨, 脛骨, 腓骨の Metaphyse から Diaphyseにかけて打抜き様の透明巣を認めた。しかし胸 
部所見では肺に転移棵と思えるるのなく，右下葉の陰 影は肺炎を併発している像であるとの内科医の返事を 得た. 血液所見で著明な颁血と自血球増多症及び血沈 値の立進を喼めたため一般状態の改尊をうる目的で先 ず輸血及び抗生物質の投与を行つたが解熱の傾向な く, 一般状態子悪く, 診断確立のため, 病理試験的鳔 本切除を行う機会がなかつた．2週後始めて解熱の傾 向を示し，一般状態む良好となり血液像可恢復の徵を 示したので再度レ線検查のためめレ線科に紹介した。 その際輸送中左銷骨の病的骨折を扢こした為観血的整 復術を行うと共にこの部より病理試験的切除標本を採 取した.この時のレ線像は両上腕, 前腕, 指骨, 腰骨,

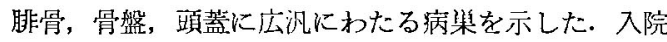
当初より抗生物䓄の投与とともに Tespamin の 1 日 $5 \mathrm{mg}$ 筋注を，血液像の籃視のもとに施行したが，2 週 後には解熱上共に白向球数も2300 と減少したためや むなく中止したが，腰痛はすでに著明炡成退した．又 レ線照射を行う予定であつたが病梁広汹な為めと血液 像悪化の為施行することが出来なかつた．其の後病理 標本の結果は Reticulosarkom であることを教示して くれた。

3 月下旬右前額部化直径 $3.0 \mathrm{~cm}$, 後頭部に直径 $5.0 \mathrm{~cm}$ の腫留を触れるようになり，在前额部の腫幦を摘出し たが，腫瘍は灭白色貧血性を示し，出血も著明でなか つた. 病理標本を作製し，病理学教室の衫断でさらに Reticulosarkomであることを確認した．4月 27 日頃

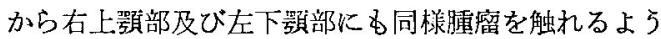
になり，比較的急速に腫癌の增大を及，食物撕取が不 能になつたためレ線空中照射 1 日 300 てを行つたとこ

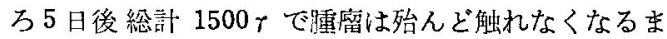
でに縮少し，食事提取も可能となつたが患者の一般状 態は一段と悪化していつた．又左鎖の擮血似整復術施 行部は異常に腫大し，小児于掌大に迄增大したが熱感 る压痛るなからた。この間表在淋巴腺の隀脤は身体の 何処なる部位にも触知せず Bence Jones 蛋向体も証明 乙得なからた。 5 月 8 日から喛濑とそれ《伴了腰部痛 を訴之 $38^{\circ}$ 代の熟発を涊め左下肺野飞湿性亏音を㱬取 したため抗生物質等の投与を行つたが，解熟すること なく食忿著明に減退し，浅眠状態を続け5月 17 日つ いに死亡した。死後直ちに剖検を行つたが肺にところ ぞころ壊死样空间を認めたが，これが肺エソであるか 睡嫁転位後の壊死性变化であるかは標本䧍索の結果で ないと不明である，又骨病策は骨髓腔全般にわたり皮
䓄部子破壊消众し灰黄色比較的弹性軟となり，肉芽組 織が充媜していたが 軟部組織への破壊浸潤は認めな かつた．表在淋巴腺の腫脹は認めなかつたが，肺門淋 巴腺，腸間膜淋巴腺の腫脹を認めた。肝への転位はな

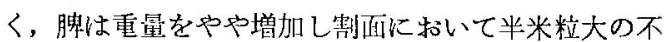
明膫な淡黄任の琉点を認めた.

しかし各部位の咩細は組織学的検索後でないと不明 である。

摘出標本による組織学的所見としては本標本が全体 に亘つて円形の核を有する比較的大きな緗胞がわずか に多発育中心性の構造を示しながら增殖している像が みられる.間質は非常比狭く所々に見られる毛細管の 周囲に少量認められる程度である。強抎大の標本をみ ると細胞体は多角形で比較的大きく，稍々エオジン好 性で各細胞は亚に細胞哭起に上り連絡しているょうに み之る。核は略正门版汇近く胞体の中央に位置し淋巴 球の核の $3 \sim 4$ 傍大と思われる.クロマチンは中等量 で核の構造る比較的良く分別されるが，車軸状や分葉 状のものは認めない，胞体及び核は全体として略々均 等した大きさを示し多形性は見られないが，非定型性 有系分裂像も各所に 見られるので本腫散細胞のなみ
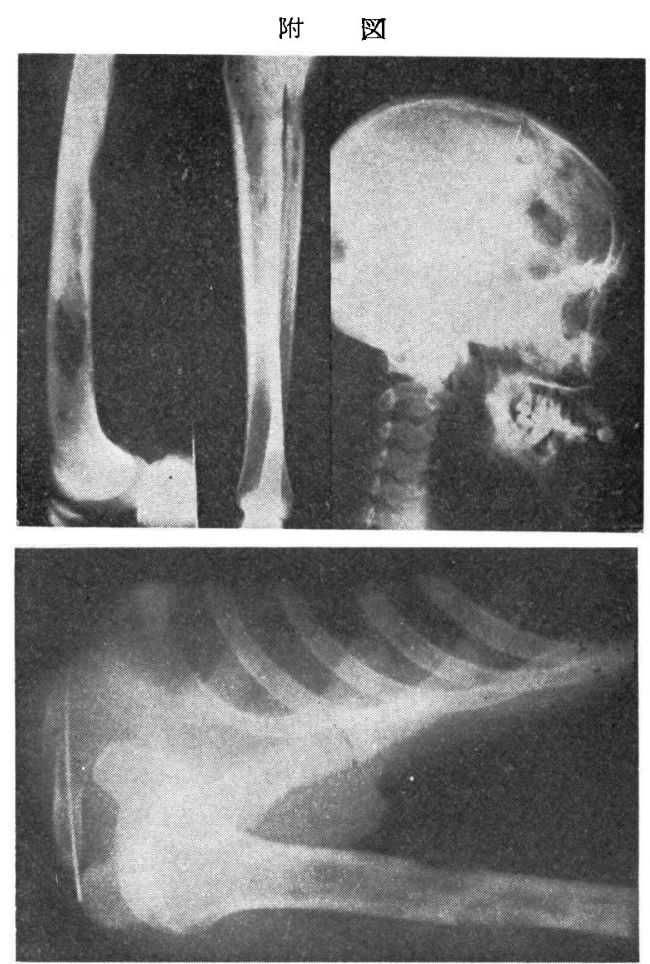
附㘣

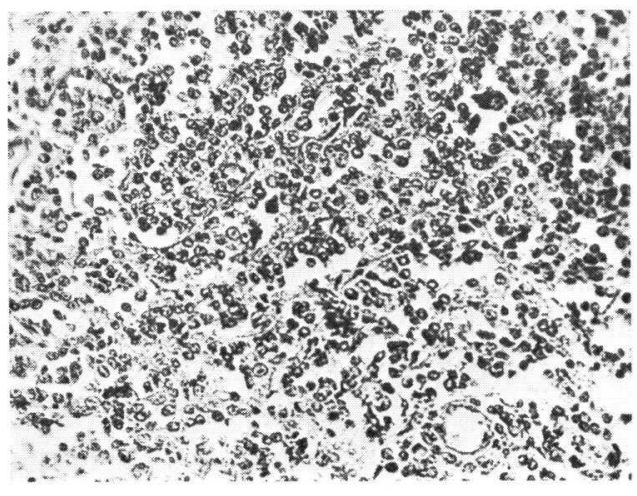

(ヘマトキシリンエオジン染色)

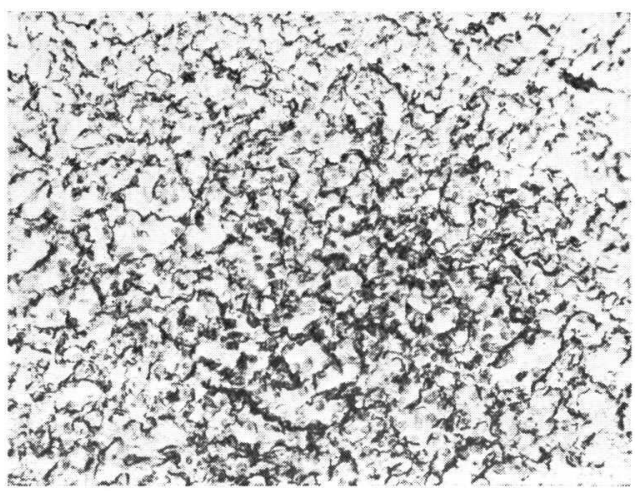

（渡 銀 染 色）

なみならぬ発育状態が想像される。渡銀染色に打いて は, 各細胞間に連絡する如く多数の奵銀線維が縱㮛に 走つて網目状構造をなしているのが認められる. 以上 の如き所見から本腫場は淋巴腺に発生する細網肉腫と 甚だ類似せるるのと考察される。

\section{考按}

骨の細網肉腫は他の悪性腫㬞とくに Ewing 氏腫瘍 との間に種々論議のあるところであるが, 臨床的経過, 上線所見, 病理組織学的所見, 乞の他の発生状況上り 明らか以区別さるべきるのであることは, 最近の報告 例にもみられるとこるである. 寸なるらら臨床的経過が 他の悪性腫境に比して比較的綵慢であること, 発生年:

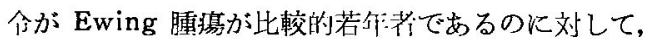
木腫墽は 30 代以上に兄ることが多いこと， Ewing のよ5k局所火炎症性 反応のない事, 又この腫揘は Ewing と共にレ線後療に 非常に感受性が高いこと.
更に病理組織学的にもEwing 腫瑝々は極めて近い相 関にはあるが，形態的にも或る程度の相違点があるこ とである. 先ず発生年令をみると Iving and Dahlin

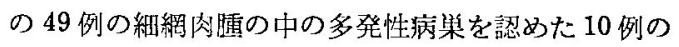
発育平均华领は 37 才であり，この5ち 20〜29才台の あのが 50\%を占めている事実は, 本症例と一致する. 部位的発生頻度をみると, 主煌長管状骨の Metaphyse に見られ，Schobinger は下肢骨盤，上肢，屃胛骨， 椎体, 頭蓋の順に頻度が高く, Hausberg, Kenin 飞 上ると下肢及び骨盤が 70\%を占めると云う. 臨床症 状として現われるのは先ず疼痛である. 疼痛はりウマ 于様であることが多く比較的長期間持続する. この症 例る腰部外傷を受けるをでは激烈な疼痛を感じたこと なく、特に压痛を訴える所るなかつた. Schobinger に上ると局所压痛及び熱感を触れる時期は病集の進展 が著明である時期であると云5．又病的骨折も約 $25 \%$ に認めると云う．所属淋巴腺に転移を来たすことが特 長と云われるが本症例では表在淋巴腺をどこにも触知 することが出来なかつた、レ線所見による鑑別診断は 非常に困難とされている. 即ち本腫場は主に, Osteolytisch な骨破壊像を見るるのであるが時に反応性骨 增殖も認められる. Schinz は Osteolyse と Osteosklerose が混在すると述べ骨膜性反応は非常に少な いと云了. 本例はレ線上助骨に骨形成性変化を認める が，他の部はすべて骨破壊像いわゆる境界比較的鮮明 な透明像を示す. レ線像より木腫場が Ewing 睡場 及び Myelom にも頑似するかの如き所見はあるが， Ewingk比すと骨形成性変化にとぼしく Myelom に 比すと胁骨の硬化像はこれに適合しない.Schobinger 及びWeston等は悪性腫韵と良性腫演との鑑別に血管 造影を行い㲜脉期及び静脉期に批ける特有な所見を見 山しているが，本例にも施行した所では彼等の言及す る所見を見出寸事が出来なからた。病理組織学的な所 見が木症の診断を確定する大きな指標になることは申 す迄もない，本症を細網肉腫と考学る由縁は本腫堭細 胞が比較的大きな円形核を有する多形細胞よりなりそ の構造は間質にとぼしく各細胞は瀻細な細胞乫起によ り速絡するごとく，ままり著明ではないが，多中心性発 生性連圈状の像を呈するところから，これが淋巴腺原 発の細網肉腫とはなは艺類似すると思はれる。しかも 渡銀染色に抢いて，はなはだ豊富な好銀線維を有する ことが本睡演が所謂細網肉䐟と云われる特質を良く表 
明するものと考えられる. 本腫瘍が骨髄原発の細網肉 畽であるとすれば, Ewing 腫瘍や Myelom との鑑 別が必然的に起つてくるが Ewing が最初に指摘した Ewing 畽凗と比較して考えると, 本腫瘍細胞は比較 的血管にとぼしく間質ははなはだ稀少であり，細胞体 及び核の大きさもやや大型であり, その全体の構成や 細胞体個々の性質についても定型的 Ewing 腫㾤とは はなはだその像を異にすると思われる，又 Myelom との鑑別であるが骨䯣腫の多くは Plasmazellen であ りその他の造血細胞腫は非常に稀であると云われる.

又本腫瘍細胞が形質細胞腫と鑑別される為には更らに 特殊染色が必要である. しかしながら短小部分の標本 のみによつてすべてを解決することは危険であると云 わねばならぬ。

\section{む す び}

以上の如き臨㦿的所見，レ線所見及び組織学的所見 から一応骨原発性細網肉腫と診断した。

追 加
血液 像 経 时 的変 化

\begin{tabular}{|c|c|c|c|c|}
\hline & $4 / 3$ & $23 / 3$ & $1 / 4$ & $11 / 5$ \\
\hline 色素量 & $55 \%$ & $60 \%$ & $88 \%$ & $54 \%$ \\
\hline 血球数 & $2987 j$ & 343万 & 414 万 & $228 \%$ \\
\hline 血球数 & 11900 & 2300 & 4950 & 2800 \\
\hline 分 類 & $\%$ & $\%$ & $\%$ & $\%$ \\
\hline 末巴球 & 21 & 18 & 19 & 46 \\
\hline 單核球 & 1 & 1 & 3 & 6 \\
\hline 塩 球 & 0 & 0 & 0 & 0 \\
\hline 酸 球 & 0 & 0 & 0 & 1 \\
\hline 葉 核 & 66 & 77 & 72 & 38 \\
\hline 狀 核 & 10 & 4 & 6 & 9 \\
\hline 沈値 & 69.50 & 21.75 & 23.50 & 57.50 \\
\hline $\begin{array}{l}\text { アルカ } \\
\text { 血清 }\end{array}$ & $\begin{array}{l}\text { リフォス } \\
\mathrm{Ca}\end{array}$ & ファタ・ーゼ & $\begin{array}{l}14.0 \\
13.2\end{array}$ & $\begin{array}{l}\text { B.u. } \\
\mathrm{mg} / \mathrm{dl}\end{array}$ \\
\hline 血淸 & $\mathrm{Na}$ & & 143.0 & "I \\
\hline $\begin{array}{l}\text { 血清 } \\
\text { Bence }\end{array}$ & $\begin{array}{l}\mathrm{K} \\
\text {-Jone }\end{array}$ & & $\cdot \begin{array}{l}4.4 \\
(-)\end{array}$ & "I \\
\hline
\end{tabular}

55 才の女子. 左肩朋骨が原発巣と考えられる細網 肉腫で，右大酿骨下部及び全身皮膚へ転移を来たした 症例を追加する.

ナイトロミン療法で皮膚の腫瘤は消失しつつある が, 左肩胛骨, 鎖骨, 右大腿骨の病巣はレ線治療に対 しても好転の徴候はない。

\section{外 傷 性 股 関 節 脱 $⿴$ 一 $の 4$ 例}

\begin{tabular}{|c|c|c|}
\hline \multirow[t]{2}{*}{ 中国労災病院整形外科 } & 木 & 下 \\
\hline & 平 & 川 \\
\hline
\end{tabular}

Four Cases of Traumatic Disiocation of the Hip Joirt.

By

\section{H. Kinoshita and H. Hirakawa}

Dept. Orthop., Chūgoku Labours Casuality Hospital

吾々は最近 4 例の外傷性股関節脱臼を経験したが, 症例は表 1 の如く, 内 3 例は受甥後 2 力月乃至 3 年を 経た陳旧例である.（表 1 ）

症例 1 ：受傷後直ちに某外科に入院したが, 1 力 月後脱臼を発見され，全麻の下に徒手整復を受け，口 ーレンツ第 1 肢位類似のギプス固定, 1 力月後ギプス を除去して退院した。しかし，その間レ線撮影を受け ず，更に他の医師を訪れたところ，なお脱臼を指摘さ れて, 受傷後 3 ケ月で当科に転じた。 入院時股関節は 強度屈曲, 外転外旋位にあり, 他動的に僅かな運動性 を有していた，大胧基部は巾広くみえ，内転筋箇をふ
表 1 外傷性股関節膲臼症例

\begin{tabular}{|c|c|c|c|c|c|c|}
\hline $\begin{array}{l}\text { 番 } \\
\text { 号 }\end{array}$ & 姓 & $\begin{array}{l}\text { 年- } \\
\text { 令 }\end{array}$ & 性 & $\begin{array}{l}\text { 職 } \\
\text { 業 }\end{array}$ & 診断 & 受傷後 \\
\hline 1 & & 39 & $\hat{o}$ & 頤 & $\begin{array}{l}\text { 左陳旧性前方 } \\
\text { (会㓌) 脫田 }\end{array}$ & 3 力月 \\
\hline 2 & & 27 & $\hat{o}$ & $\begin{array}{l}\text { 運 } \\
\text { 送 } \\
\text { 員 }\end{array}$ & 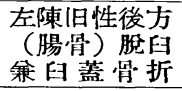 & 2.5 力月 \\
\hline 3 & & 24 & $\hat{o}$ & 工 & $\begin{array}{l}\text { 右陳旧性 } \\
\text { 中心性脫兒 }\end{array}$ & 3 力年 \\
\hline 4 & & 70 & $\hat{\delta}$ & $\begin{array}{l}\text { 無 } \\
\text { 職 }\end{array}$ & 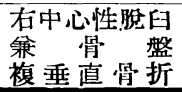 & 9 日 \\
\hline
\end{tabular}

